\title{
URIC ACID METABOLISM IN PSORIASIS
}

\author{
By ARTHUR Z. EISEN * AND J. E. SEEGMILLER \\ (From the Dermatology Branch, National Cancer Institute, and The National Institute of \\ Arthritis and Metabolic Diseases, National Institutes of Health, Bethesda, Md.)
}

(Submitted for publication March 6, 1961 ; accepted April 7, 1961)

Hyperuricemia has been noted to occur in approximately 30 to 40 per cent of patients with psoriasis (1-5). The cause of the hyperuricemia and its possible relation to the psoriatic process has received very little attention.

Uric acid synthesis has been evaluated in man by determining the turnover of injected isotopically labeled uric acid as well as by the incorporation of isotopically labeled glycine into urinary uric acid. Observations made on subjects with primary gout have shown that there is a prompt incorporation of glycine-1- $\mathrm{C}^{14}$ or glycine- $\mathrm{N}^{15}$ into urinary uric acid (6-13) while in gout secondary to proliferative disorders of the hemopoietic system, isotopic incorporation is delayed presumably because the major pathway of uric acid synthesis involves the incorporation of glycine into tissue purines with their slower rate of turnover (14, $15)$.

In psoriasis, the skin lesion is a result of hyperplasia of the epidermis in which the rate of cellular reproduction is accelerated to such an extent that maturation of the epidermal cells and the process of normal keratinization do not occur (16). By analogy with the hyperuricemia seen in myeloproliferative diseases, it is possible that the hyperuricemia of psoriasis may reflect an increased nucleic acid turnover resulting from the marked acceleration of epidermal proliferation that occurs in this disease.

The present study was undertaken to determine whether the pattern of glycine-1-C $\mathrm{C}^{14}$ incorporation into urinary uric acid in psoriasis resembles that seen in primary or in secondary gout. Uric acid$\mathrm{N}^{15}$ was used to obtain information on the dynamics of the body urate pool and to provide an independent parameter of uric acid synthesis.

\section{METHODS}

Studies were performed on 5 patients with active psoriasis, on 1 patient with gout and psoriasis and on 2

* Present address : Dept. of Medicine, Rochester School of Medicine and Dentistry, Rochester, N. Y. control subjects. The patient with gout and psoriasis (F.M.) had a history of frequent attacks of acute arthritis which responded to colchicine. A synovial biopsy of his left knee revealed characteristic deposition of urate crystals. The control subjects had no family history or stigmata of either psoriasis or gout. Remission of psoriasis occurred in one patient (L.P.) following a severe drug eruption resulting from the oral administration of chloroquin phosphate. Within 2 weeks after the drug had been discontinued, complete healing of the skin had occurred and no lesions of psoriasis were present. The repeat glycine-1- $\mathrm{C}^{14}$ incorporation study was carried out approximately 10 weeks after the last dose of chloroquin had been administered, while the psoriasis was still in complete remission.

All subjects were hospitalized throughout the studies and were maintained on a standard 2,600 calorie diet, essentially free of purines and containing $70 \mathrm{~g}$ of protein, $350 \mathrm{~g}$ of carbohydrate and $100 \mathrm{~g}$ of fat. At least 5 days were allowed for equilibration on the diet before the studies were performed. Patients received no medication during the study. The clinical diagnosis of psoriasis in each case was confirmed by skin biopsy. Renal function was assessed by routine urinalysis, blood urea nitrogen and phenolsulfonphthalein excretion.

Daily 24-hour urine collections were preserved with toluene and stored at room temperature. Serum and urinary uric acid determinations were performed by means of the enzymatic spectrophotometric assay of Praetorius and Poulsen (17) as modified by Liddle, Seegmiller and Laster (18). The upper range of normal for the 24-hour urinary uric acid excretion on the standard purine-free diet was considered as $600 \mathrm{mg}$ per day (13). A serum urate value of $6.0 \mathrm{mg}$ per $100 \mathrm{ml}$ for males and $5.0 \mathrm{mg}$ per $100 \mathrm{ml}$ for females by the colorimetric method of Archibald (19), corresponding to a value of $6.2 \mathrm{mg}$ per $100 \mathrm{ml}$ for males and $5.2 \mathrm{mg}$ per 100 $\mathrm{ml}$ for females by the enzymatic method, was taken as the upper limit of normal. These values are only slightly more than 1 standard deviation from the mean for the serum urate values of a large group of normal subjects combined from the literature, $5.1 \pm 0.98 \mathrm{mg}$ per $100 \mathrm{ml}$ for 969 males and $4.0 \pm 0.93 \mathrm{mg}$ per $100 \mathrm{ml}$ for $168 \mathrm{fe}-$ males (20). Extension of the range of normal values to include 2 standard deviations above the mean $(7.0 \mathrm{mg}$ per $100 \mathrm{ml}$ for males and $5.9 \mathrm{mg}$ per $100 \mathrm{ml}$ for females) would result in a substantial number of patients with conditions associated with "hyperuricemia" being included in the upper range of normal.

Glycine-1-C ${ }^{14}$ with a specific activity of $1.0 \mathrm{mc}$ per mmole (Volk Radiochemical Corporation of Chicago) 


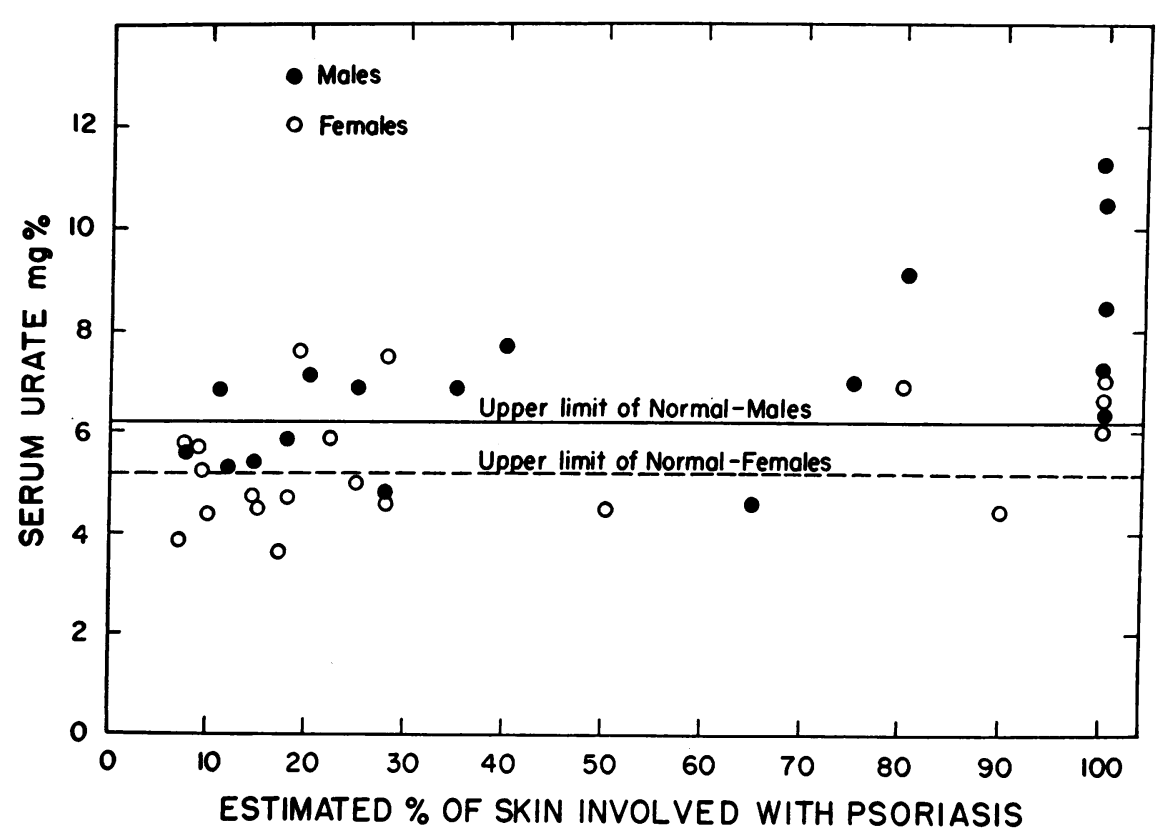

Fig. 1. Serum urate values correlated with the estimated percentage of SKIN INVOLVEd WITH PSORIASIS. The correlation coefficient $\mathrm{R}=0.567$. The above determinations of uric acid were performed using the enzymatic spectrophotometric method. The values shown for the upper limits of normal of $6.2 \mathrm{mg} \%$ for males and $5.2 \mathrm{mg} \%$ for females correspond to values obtained by the Archibald colorimetric method of 6.0 and $5.0 \mathrm{mg} \%$, respectively (19).

was given orally in a single dose of 5 or $10 \mu \mathrm{c}$ with the breakfast milk. Simultaneously, $36 \mathrm{mg}$ of uric acid $1,3-\mathrm{N}^{15}, 1$ containing 28.6 atom per cent excess of $\mathrm{N}^{15}$, was administered intravenously as the lithium salt to measure the urate pool and to allow corrections to be made for altered dynamics of this pool. Samples of uric acid for intravenous injection were sterilized by filtration of the lithium salt in $\mathbf{5}$ per cent glucose solution through a $0.45 \mu$ Millipore filter.

Uric acid was isolated from the urine either by adsorption onto activated charcoal (21) or by precipitation as a copper salt when urine volumes exceeded $1,500 \mathrm{ml}$ per day (22), and purified by repeated crystallization from lithium carbonate solution by addition of acetic acid (23). The radioactivity was determined using an end-window gas-flow counter (Nuclear Chicago), from planchets prepared at infinite thickness. All specific activity values were corrected to a standard dose of $5 \mu \mathrm{c}$ of glycine-1- $\mathrm{C}^{\mathbf{1 4}}$. The $\mathrm{N}^{15}$ content of the uric acid was determined in a $60^{\circ}$ Consolidated Nier mass spectrometer following preliminary Kjeldahl digestion (24).

\section{RESULTS}

Hyperuricemia was associated with psoriasis in 50 per cent of 38 patients with this disease seen

\footnotetext{
1 We are indebted to Miss Jean D. Benedict for providing the uric acid- $\mathrm{N}^{15}$.
}

at the Clinical Center during the past 18 months. In 10 of the 18 males the serum urate values ranged from 6.6 to $11.3 \mathrm{mg}$ per $100 \mathrm{ml}$. The values for seven of these patients are undoubtedly lower than their usual levels by approximately 1.0 $\mathrm{mg}$ per $100 \mathrm{ml}$, since they were being maintained on a purine-free diet at the time the determination was made (13). The three remaining males of this group showed serum urate values above 7.1 $\mathrm{mg}$ per $100 \mathrm{ml}$. Nine of 20 female patients had serum urate levels ranging from 5.4 to $7.6 \mathrm{mg}$ per $100 \mathrm{ml}$. None of these 38 patients had a family history of gout and there was no clinical or laboratory evidence of associated renal, hepatic or hematologic disease which might result in hyperuricemia. Fourteen patients had a nongouty type of arthritis which is frequently associated with the psoriatic process and of these, eight had elevation of the serum urate. In this small series, patients with extensive involvement of the skin tended to have a higher incidence of hyperuricemia (Figure 1 ), suggesting that the elevation of the serum urate may be associated with excessive epidermal proliferation. 
Data on subjects given glycine-1-('14

\begin{tabular}{|c|c|c|c|c|c|c|c|}
\hline \multirow[b]{2}{*}{$\begin{array}{l}\text { Subject, } \\
\text { Age, Race, } \\
\text { Sex }\end{array}$} & \multirow[b]{2}{*}{$\mathrm{Wt}$} & \multirow[b]{2}{*}{ Clinical summary } & \multicolumn{2}{|c|}{ Serum uric acid } & \multirow[b]{2}{*}{$\begin{array}{l}\text { Urinary } \\
\text { uric acid }\end{array}$} & \multicolumn{2}{|c|}{ Renal function* } \\
\hline & & & $\begin{array}{l}\text { Before } \\
\text { diet }\end{array}$ & $\begin{array}{l}\text { After } \\
7 \text { days } \\
\text { on diet }\end{array}$ & & BUN & $\begin{array}{c}\text { PSP } \\
(2 \mathrm{hr})\end{array}$ \\
\hline & $\mathrm{kg}$ & & $m g \%$ & $m g \%$ & $m g / d a y \pm S D \dagger$ & $m g \%$ & $\%$ \\
\hline 38, W, & 78.5 & $\begin{array}{l}\text { Control subject, small basal } \\
\text { cell carcinomata on face }\end{array}$ & 3.4 & 3.2 & $357 \pm 51$ & 11 & 67 \\
\hline $\begin{array}{l}\text { P.D. } \\
19, \mathrm{~W}, \sigma^{7}\end{array}$ & 65.5 & Normal volunteer & 4.5 & 4.5 & $459 \pm 56$ & 14 & 72 \\
\hline $\begin{array}{l}\text { B.P. } \\
30, W, \sigma^{7}\end{array}$ & 77.5 & $\begin{array}{l}\text { Psoriasis of } 10 \text { yrs dura- } \\
\text { tion, approximately } 80 \% \text { skin } \\
\text { involvement, no joint disease }\end{array}$ & 9.1 & 8.5 & $601 \pm 36$ & 11 & 78 \\
\hline $\begin{array}{l}\text { J.F. } \\
\text { 20, W, o }\end{array}$ & 66.7 & $\begin{array}{l}\text { Psoriasis of } 7 \text { yrs duration, } \\
\text { psoriatic arthritis for } 2 \text { yrs, } \\
\text { no acute attacks of arthritis, } \\
\text { no response of arthritis to } \\
\text { colchicine or Probenicid, } \\
100 \% \text { skin involvement }\end{array}$ & 9.7 & 6.8 & $773 \pm 78$ & 8 & 76 \\
\hline $\begin{array}{l}\text { W.M. } \\
54, \mathrm{~W}, \sigma^{7}\end{array}$ & 71 & $\begin{array}{l}\text { Psoriasis of } 25 \text { yrs duration, } \\
\text { approximately } 75 \% \text { skin in- } \\
\text { volvement, no joint disease }\end{array}$ & 7.1 & 6.9 & $631 \pm 50$ & 12 & 82 \\
\hline $\begin{array}{l}\text { W.J. } \\
31, \mathrm{~W}, \sigma^{x}\end{array}$ & 95.5 & $\begin{array}{l}\text { Psoriasis of } 13 \text { yrs duration, } \\
\text { approximately } 35 \% \text { skin in- } \\
\text { volvement, no joint disease }\end{array}$ & 5.7 & 5.8 & $557 \pm 40$ & 11 & 84 \\
\hline \multirow[t]{2}{*}{$\begin{array}{l}\text { L.P. } \\
73, \mathrm{~W}, \text { o }\end{array}$} & 70.2 & $\begin{array}{l}\text { Study } 1 \text { : psoriasis active and } \\
\text { of } 25 \text { yrs duration, approxi- } \\
\text { mately } 50 \% \text { skin involvement, } \\
\text { no joint disease }\end{array}$ & 4.9 & 4.2 & $312 \pm 32$ & 8 & 73 \\
\hline & & $\begin{array}{l}\text { Study } 2: \text { psoriasis in } \\
\text { complete remission }\end{array}$ & 4.6 & 4.8 & $223 \pm 17$ & 10 & \\
\hline $\begin{array}{l}\text { F.M. } \\
\text { 56, W, ه }\end{array}$ & 84.4 & $\begin{array}{l}\text { Psoriasis of } 13 \text { yrs dura- } \\
\text { tion, } 9 \text { yr history of acute } \\
\text { gouty arthritis, approxi- } \\
\text { mately } 60 \% \text { skin involvement, } \\
\text { chronic alcoholic, } 20 \% \text { BSP } \\
\text { retention }\end{array}$ & 8.7 & 5.6 & $548 \pm 44$ & 11 & 74 \\
\hline
\end{tabular}

* $\mathrm{BUN}=$ blood urea nitrogen $; \mathrm{PSP}=$ phenolsulfonphthalein $; \mathrm{BSP}=$ sulfobromophthalein.

$\dagger \mathrm{SD}$ refers to the standard deviation of the mean values for urinary uric acid excretion during the period of study following the administration of glycine-1-C $\mathrm{C}^{14}$.

The pertinent clinical data on the subjects included in this study are presented in Table I. Included is an estimate of the degree of skin involvement, as determined by the method of Evans and associates (25), at the time of isotope administration. Three of the patients had greater than 70 per cent and two had less than 50 per cent of their skin involved with psoriasis. In most subjects the serum urate values after 7 days on the purine- free diet were only slightly lower than the serum levels prior to initiation of the diet. In Subjects J.F. and F.M., however, the serum uric acid values decreased quite markedly after initial institution of the diet but thereafter remained at a constant level.

The specific activities of $\mathrm{C}^{\mathbf{1 4}}$ in urinary uric acid after administration of a tracer dose of glycine$1-\mathrm{C}^{14}$ are shown in Figure 2. The specific activity of uric acid obtained from control subjects 


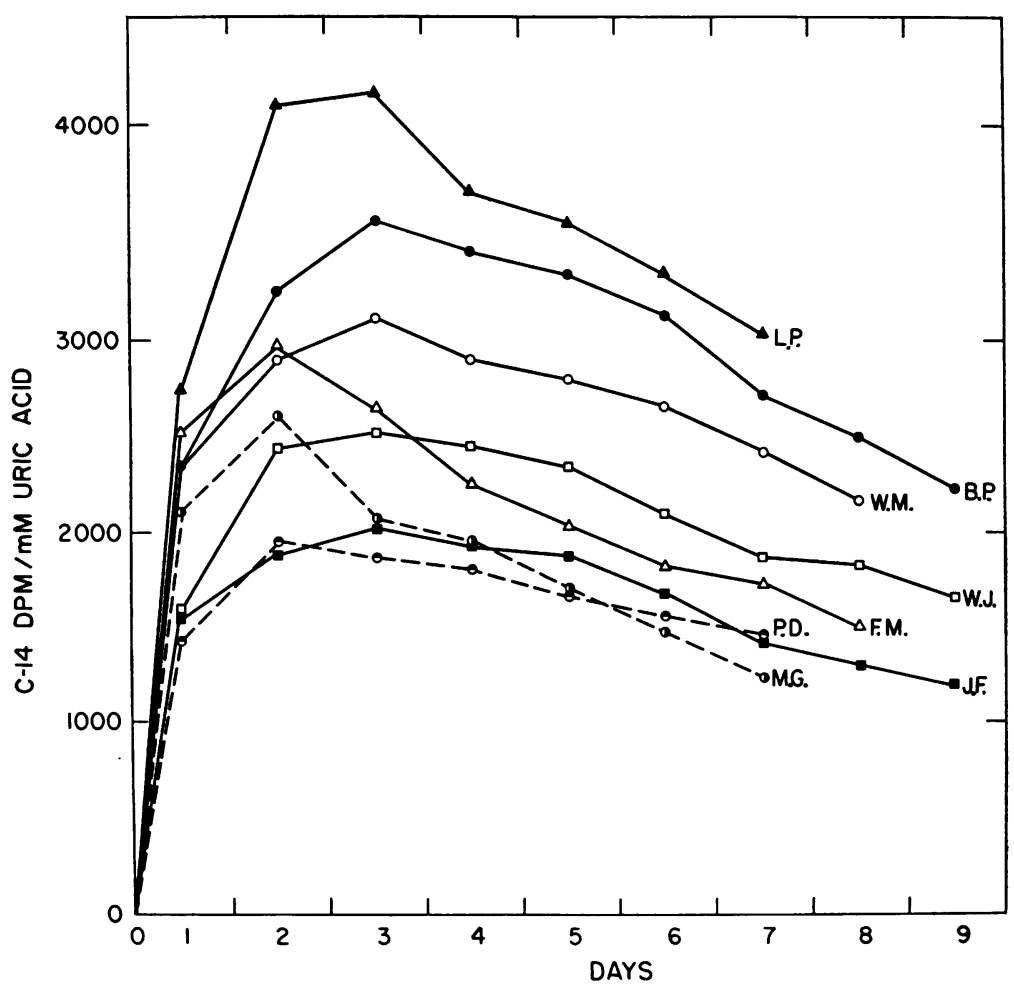

Fig. 2. Specific activity values (Disintegrations per minute per MILLIMOLE OF URINARY URIC ACID) IN CONTROL AND PSORIATIC SUBJECTS FOLLOWING ORAL ADMINISTRATION OF GLYCINE-1-C ${ }^{14}$. B.P., W.M. and J.F. were patients with psoriasis who excreted excessive quantities of uric acid in their urine (i.e., greater than $600 \mathrm{mg}$ per day). L.P. and W.J. represent patients with psoriasis who had a normal urinary excretion of uric acid. F.M. represents a patient with psoriasis and gout. The two control subjects studied were P.D. and M.G. All values are normalized to a standard dose of $5 \mu \mathrm{c}$ of glycine-1-C $\mathrm{C}^{14}$.

P.D. and M.G. was within the range that has been demonstrated by previous investigations for normal control subjects (13). In the five nongouty psoriatic patients, the specific activities rose quite rapidly, reaching a maximum on the third day, followed by a gradual decline in isotope concentration. In Patients B.P. and W.M., who excreted excessive amounts of uric acid, the maximal specific activities were considerably higher than those of the control subjects. Patient J.F., however, who also produced excessive amounts of uric acid in his urine, showed a maximum specific activity within the range of the control subjects. The fact that he showed no extrarenal disposal of uric acid (Table II) may account in part for his high urinary production of uric acid.

Patient L.P. is of particular interest; the specific activity of $\mathrm{C}^{14}$ in her urinary uric acid was the highest of all the subjects studied, reaching a maximum of 4,291 dpm per mmole of uric acid on the third day after the isotope was administered. At the time this patient was studied, both her serum and urinary uric acid levels were well within normal limits. This is most unusual, since excessively high concentrations of isotope in the uric acid are most often associated with elevated serum and urinary levels $(12,13)$. In W.J., who also had normal serum and urinary uric acid levels, the pattern of incorporation closely resembles that of the other psoriatic patients.

The association of psoriasis with gout has been reported $(5,26)$. Patient F.M. demonstrated such an association, and was studied in an effort to determine whether his pattern of glycine incorporation into urinary uric acid resembled that of primary gout or psoriasis. The peak specific ac- 
TABLE II

Seven-day recovery of isotope in urinary uric acid

\begin{tabular}{cccc}
\hline \hline & $\begin{array}{c}\text { Per cent of } \\
\text { administered } \\
\text { uric acid-N } \\
\text { (a) }\end{array}$ & \multicolumn{2}{c}{$\begin{array}{c}\text { Per cent of admin- } \\
\text { istered glycine-1-Ci4 }\end{array}$} \\
\cline { 3 - 4 } & & $\begin{array}{c}\text { Uncorrected } \\
\text { (b) }\end{array}$ & $\begin{array}{c}\text { Corrected } \\
(\mathbf{b} / \mathbf{a} \times 100)\end{array}$ \\
\hline Controls & & & \\
M.G. & 82.1 & 0.27 & 0.34 \\
P.D. & 77.0 & 0.29 & 0.37 \\
Psoriasis & & & \\
B.P. & 64.4 & 0.70 & 1.09 \\
J.F. & 99.3 & 0.51 & 0.52 \\
W.M. & 81.5 & 0.69 & 0.84 \\
W.J. & 74.1 & 0.45 & 0.61 \\
L.P.* & 53.0 & 0.42 & 0.32 \\
L.P.† & & 0.17 & \\
Psoriasis & & & \\
and gout & & & \\
F.M. & 70.2 & 0.48 & 0.69 \\
\hline
\end{tabular}

* Study 1 : psoriasis active; patient did not receive uric acid- $\mathrm{N}^{15}$.

$\dagger$ Study 2: psoriasis in remission.

tivity of $\mathrm{C}^{14}$ in this subject's urinary uric acid was reached on the second day and declined more rapidly than in the other psoriatic patients. This pattern tends to resemble more closely that found in

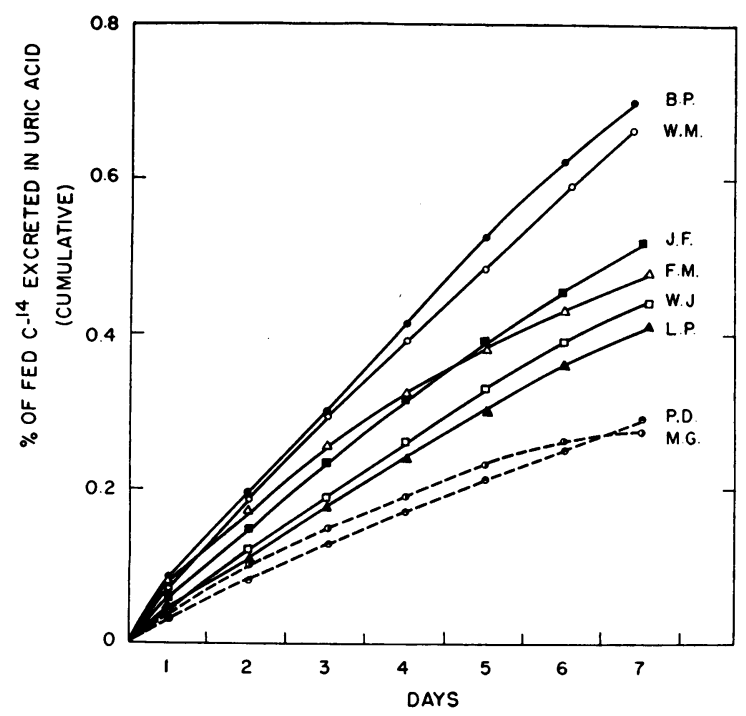

Fig. 3. Cumulative incorporation of gLycine-1-C ${ }^{14}$ INTO URINARY URIC ACTD OF SUBJECTS PRESENTED IN FIGURE 1. B.P., W.M. and J.F. are patients with psoriasis who excreted excessive amounts of urinary uric acid. L.P. and W.J. are patients with psoriasis who had a normal urinary excretion of uric acid. F.M. is a patient with psoriasis and gout. P.D. and M.G. are control subjects. subjects with primary gout rather than the pattern shown by the other psoriatic patients studied.

The cumulative recovery of isotope in the urinary uric acid during the 7 days following the administration of glycine-1- $\mathrm{C}^{14}$ is shown in Figure 3. In all five nongouty, psoriatic patients excessive incorporation of glycine-1- $\mathrm{C}^{14}$ into urinary uric acid is clearly demonstrated when compared with the control subjects; this is also true for F.M., the psoriatic patient with gout. It was not surprising that the highest percentage incorporation values were seen in those subjects who excreted abnormally large amounts of uric acid in their urine. Unexpectedly, however, Patients L.P. and W.J., who excreted normal quantities of uric acid, nevertheless incorporated excessive quantities of the isotope into their urinary uric acid.

Substantial uricolysis has been demonstrated to occur in man (27). Furthermore, with hyperuricemia there is a possibility of urate deposition in tissues. Such extrarenal disposal of uric acid has been shown in some gouty patients to alter substantially the cumulative recovery values obtained by measurements of urinary uric acid alone (13). The magnitude of such extrarenal disposal of uric acid is indicated by the percentage of the injected uric acid- $\mathrm{N}^{15}$ which is recovered in the urine. Table II demonstrates the wide variation in this parameter among these patients.

By correcting the cumulative $\mathrm{C}^{\mathbf{1 4}}$ recovery values for the fraction of the daily uric acid production that fails to appear in the urine, it is possible to estimate the total amount of $\mathrm{C}^{\mathbf{1 4}}$ incorporated into uric acid within the body. These values, shown in Table II, serve to emphasize the degree of overincorporation of isotope demonstrated by the psoriatic subjects when compared with the control subjects.

In addition to the evaluation of extrarenal disposal of uric acid, the use of uric acid $1,3-\mathrm{N}^{15}$ permitted an estimation of the urate pool size and turnover which is shown in Table III. The urate pool size in these subjects seemed to be a reflection of their serum urate levels. Calculations indicated that there was no solid phase urate in their miscible pools (28). Although the turnover values for the patients with psoriasis were greater than those of both control subjects, other investigators (6, 29) have found turnover values in some control subjects that overlap with the values we obtained 
TABLE III

Miscible urate pool size and turnover

\begin{tabular}{|c|c|c|c|c|c|c|}
\hline Subject & $\begin{array}{l}\text { Mean serum } \\
\text { uric acid }\end{array}$ & $\begin{array}{c}\text { Urate } \\
\text { pool size } \\
\text { (A) }\end{array}$ & $\begin{array}{c}\text { Turnover } \\
\text { rate } \\
\text { (K) }\end{array}$ & $\underset{\text { (KA) }}{\text { Turnover }}$ & $\begin{array}{l}\text { Excretion of } \\
\text { uric acid } \\
\text { (E) }\end{array}$ & $\begin{array}{c}\text { Per cent of } \\
\text { turnover } \\
\text { excreted } \\
(\mathrm{E} / \mathrm{KA} \times 100)\end{array}$ \\
\hline Control & $m g \%$ & $m g$ & pools/day & \multicolumn{2}{|c|}{$m g / d a y$} & \\
\hline $\begin{array}{l}\text { M.G. } \\
\text { P.D. }\end{array}$ & $\begin{array}{l}3.2 \\
4.5\end{array}$ & $\begin{array}{r}687 \\
1,162\end{array}$ & $\begin{array}{l}0.738 \\
0.559\end{array}$ & $\begin{array}{l}506 \\
650\end{array}$ & $\begin{array}{l}357 \\
459\end{array}$ & $\begin{array}{l}71.0 \\
70.6\end{array}$ \\
\hline \multicolumn{7}{|l|}{ Psoriasis } \\
\hline $\begin{array}{l}\text { B.P. } \\
\text { J.F. } \\
\text { W.M. } \\
\text { W.J. } \\
\text { L.P.* } \\
\text { L.P.† }\end{array}$ & $\begin{array}{l}8.5 \\
6.8 \\
6.6 \\
5.8 \\
4.2 \\
4.7\end{array}$ & $\begin{array}{r}1,860 \\
1,221 \\
1,348 \\
1,381 \\
880\end{array}$ & $\begin{array}{l}0.435 \\
0.621 \\
0.551 \\
0.490 \\
\\
0.454\end{array}$ & $\begin{array}{l}809 \\
772 \\
743 \\
677 \\
\\
400\end{array}$ & $\begin{array}{l}601 \\
773 \\
637 \\
549 \\
312 \\
223\end{array}$ & $\begin{array}{c}74.0 \\
100 \\
87.1 \\
82.5 \\
\\
55.7\end{array}$ \\
\hline \multicolumn{7}{|c|}{ Psoriasis and gout } \\
\hline F.M. & 5.6 & 1,297 & 0.585 & 749 & 556 & 73.2 \\
\hline
\end{tabular}

* Study 1 : psoriasis active; patient did not receive uric acid- ${ }^{15}$.

† Study 2: psoriasis in remission.

for the patients with psoriasis. The last column of Table III provides an independent evaluation of extrarenal disposal which is in general agreement with recovery values shown in Table II.

Effect of remission of psoriasis on uric acid biosynthesis. The occurrence of a remission of psoriasis in Patient L.P. provided an opportunity to evaluate the extent to which the psoriatic process may have contributed to the abnormal glycine incorporation. A repeat study was performed 2 months after complete clearing of the skin (4 months after completion of the initial study). As shown in Figure 4, the specific activity of $\mathrm{C}^{14}$ in urinary uric acid had decreased markedly with remission of the psoriasis, and the pattern of incorporation closely resembles that of the control subjects. The cumulative percentage incorporation values were also within the same range as those shown by the control subjects.

\section{DISCUSSION}

In previous studies of the pattern of incorporation of either glycine-1- $\mathrm{C}^{14}$ or glycine- $\mathrm{N}^{15}$ into urinary uric acid, most patients with primary gout, as well as most normal subjects (13), have shown a maximal specific activity on the first or second day. An occasional normal subject, however, has shown a maximal specific activity on the third or even the fourth day. By contrast, patients with gout secondary to myeloproliferative disorders studied with glycine- $\mathrm{N}^{15}$ showed low specific activities during the first few days with a progressive increase to maximal values on the tenth to fourteenth day $(14,15)$. One patient with agnogenic myeloid metaplasia studied with glycine-1-C $C^{14}$ (30) showed a maximal specific activity in urinary uric acid on the third day; however, the isotope con-

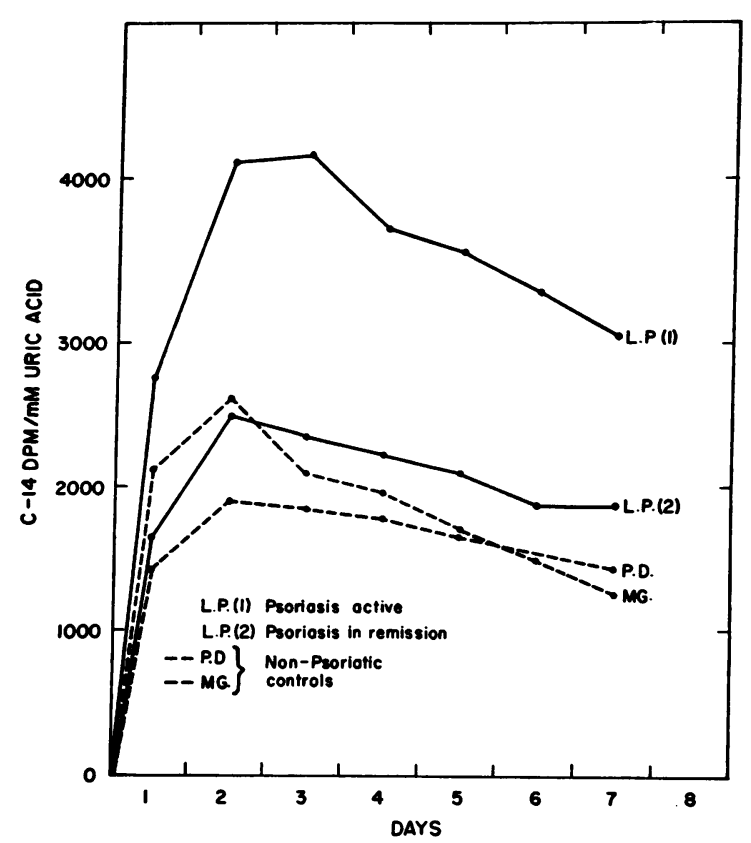

Fig. 4. SPEcific activity vatues (Disintegrations PER MINUTE PER MILLIMOLE OF URINARY URIC ACID) IN Control subjects and in Patient L.P. 
centration during the ensuing days declined less rapidly than in patients with primary gout or in the control subjects, with evidence of a secondlary phase of $\mathrm{C}^{14}$ incorporation into uric acid which was maximal on the eleventh to thirteenth day. The fact that the life span of the circulating granulocytes is approximately 13 days suggests that the turnover of granulocyte nucleic acid may be related to the delayed appearance of isotope in urinary uric acid (31).

The pattern of glycine-1- $\mathrm{C}^{14}$ incorporation into uric acid in the psoriatic patients was consistently intermediate between that shown by patients with primary gout and that shown by patients with secondary gout. The fact that the turnover time of the stratum corneum of the epidermis in individuals with psoriasis is 3 to 4 days as compared with approximately 28 days in nonpsoriatic individuals (32), suggests that the peak enrichment of uric acid seen on the third day may, in part, be related to a more rapid turnover of nucleic acids involved in this proliferative process. In addition, the possibility exists that the relative amounts of uric acid formed directly from nucleotides has been enhanced by the psoriatic process. Patient F.M., with both gout and psoriasis, showed a maximal specific activity on the second day and therefore more nearly resembled the pattern of labeling seen in patients with primary gout than in patients with psoriasis.

All of the patients with psoriasis showed substantially greater total recoveries of $\mathrm{C}^{14}$ in the urinary uric acid over a 7-day period than did the control subjects. Correction of the glycine incorporation values for the fraction of administered uric acid- $\mathrm{N}^{15}$ that failed to appear in the urinary uric acid (Table II) serves to emphasize this difference between patients with psoriasis and the control subjects.

An independent measure of uric acid production was provided by the rate of turnover of uric acid$\mathrm{N}^{15}$ administered intravenously (Table III). Previously reported studies have shown a wide range in the values for the daily turnover of uric acid in the normal individual, with a mean turnover value in 13 such subjects of $685 \pm 88 \mathrm{mg}$ per day $(6,13,21,27,29)$. The daily urate turnover in the psoriatic patients was for the most part within the upper range of normal values except for Patient B.P. in whom this parameter was sig- nificantly elevated. The turnover of uric acid as measured by uric acid- $\mathrm{N}^{15}$ did not show a close correlation with the amount of glycine-1-C ${ }^{14}$ incorporated into urinary uric acid. In general, the incorporation of $\mathrm{C}^{14}$ into uric acid was greater than one would expect from the urate turnover values alone, suggesting that the increased incorporation of isotopically labeled glycine into urinary uric acid occurred in the face of normal or only moderate elevations in the size of the urate miscible pool and in its daily turnover.

The presence of high specific activity values as well as elevated cumulative isotopic incorporation values in the two psoriatic patients (L.P. and W.J.) who excreted normal amounts of uric acid in their daily urine, is of particular interest. It would appear that in some patients with psoriasis, such as L.P. and W.J., metabolic processes are so altered as to enhance isotopic incorporation into uric acid without a proportionate increase in net synthesis of uric acid. A similar situation has been observed in some patients with primary gout and a mechanism proposed whereby dietary glycine enters urinary urate through prompt degradation of a larger fraction of newly formed purine nucleotides without the delay that results from incorporation into nucleic acids (9). This could account for a disproportionately high glycine incorporation in the face of a moderate increase in total uric acid synthesis. Alternative mechanisms that could account for an increased incorporation of glycine into uric acid without a proportionate increase in uric acid synthesis include: $a$ ) a reduction in the size of the glycine pool which would result in less dilution of the administered isotopically labeled glycine and hence a higher specific activity of that glycine which does become incorporated into uric acid, or $b$ ) a reduction in the turnover rate of the glycine pool so that the rate of disposal of glycine by pathways other than purine synthesis is diminished, which thereby results in a larger fraction of the glycine-1- $\mathrm{C}^{14}$ remaining available for purine synthesis. Just which of the many possible explanations is operative in psoriasis has not been determined.

A diminished uricolysis has been postulated as a cause of hyperuricemia (33). The essentially complete recovery in the urine of intravenously administered uric acid- $\mathrm{N}^{15}$ in Patient J.F. indicates the absence of appreciable uricolysis in this 
patient. Further support for this conclusion is provided by the remarkable agreement of the uric acid turnover with the urinary production of uric acid in this patient. Similar results have been reported in one gouty subject (34) and have been noted as an inconstant finding in two other subjects (35). Evidence has been presented that uricolysis is the result of bacterial action on the uric acid present in intestinal secretions (27). A reasonable explanation for the apparent absence of uricolysis in Patient J.F. would be the absence of uricolytic bacteria in the intestinal flora at the time he was studied, even though no antibacterial therapy was given.

The data shown in Figure 4 in which the glycine incorporation values decreased to essentially the normal range, when the study was repeated after a remission of the active psoriatic process, suggests that this abnormality in glycine-1- $\mathrm{C}^{\mathbf{1 4}}$ incorporation into urinary uric acid was related in some manner to the active psoriatic process rather than to a persistent defect in the utilization of glycine for uric acid synthesis.

It is of particular interest that although these patients showed an increased glycine incorporation into urinary uric acid and, in some, excessive uric acid production was present, these individuals, with the exception of Patient F.M., showed no evidence of gouty arthritis.

\section{SUM MARY}

1. Nineteen of 38 patients with psoriasis were found to have an associated elevation of the serum uric acid. Patients with extensive involvement of the skin tended to have a higher incidence of hyperuricemia.

2. Five patients with psoriasis all showed a greater than normal incorporation of glycine into urinary uric acid.

3. The pattern of incorporation of $\mathrm{C}^{14}$ into urinary uric acid tended to differ from that seen in control subjects and appeared to be intermediate between that shown by patients with primary gout and those with secondary gout. The specific activity of $\mathrm{C}^{14}$ in urinary uric acid reached a maximum on the third day after administration of the isotope in all the patients with psoriasis, while one patient with gout and psoriasis showed a maximal specific activity on the second day.
4. The abnormal labeling of urinary uric acid returned to normal after clinical remission of psoriasis in one patient.

\section{ACKNOWLEDGMENT}

The authors wish to express their indebtedness to Dr. Eugene J. Van Scott for his helpful advice and suggestions during the course of this study, to Dr. Nathaniel I. Berlin for critically reviewing the manuscript and to $\mathrm{Mr}$. William Comstock for the $\mathrm{N}^{15}$ determinations.

\section{REFERENCES}

1. Herrmann, F. Harnsäureuntersuchungen bei Psoriasis. Arch. Derm. Syph. (Berl.) 1930, 161, 114.

2. Le Coultre, L. Uber die Bedeutung der Harnsäure un der Ätiologie der Psoriasis. Arch. Derm. Syph. (Berl.) 1936, 174, 650.

3. Lobitz, W., and Brunsting, L. Quoted by Ormsby, O. S., and Montgomery, H., in Diseases of the Skin, 8th ed. Philadelphia, Lea and Febiger, 1954, 313.

4. Steinberg, A. G., Becker, S. W., Jr., Fitzpatrick, T. B., and Kierland, R. R. A genetic and statistical study of psoriasis. Amer. J. hum. Genet. 1951, 3, 267.

5. Kaplan, H., and Klatskin, G. Sarcoidosis, psoriasis, and gout: Syndrome or coincidence? Yale J. Biol. Med. 1960, 32, 335.

6. Benedict, J. D., Forsham, P. H., and Stetten, DeW., Jr. The metabolism of uric acid in the normal and gouty human studied with the aid of isotopic uric acid. J. biol. Chem. 1949, 181, 183.

7. Benedict, J. D., Roche, M., Yü, T. F., Bien, E. J., Gutman, A. B., and Stetten, DeW., Jr. Incorporation of glycine nitrogen into uric acid in normal and gouty man. Metabolism 1952, 1, 3.

8. Benedict, J. D., Yü, T. F., Bien, E. J., Gutman, A. B., and Stetten, DeW., Jr. A further study of the utilization of dietary glycine nitrogen for uric acid synthesis in gout. J. clin. Invest. 1953, 32, 775.

9. Wyngaarden, J. B. Overproduction of uric acid as the cause of hyperuricemia in primary gout. $\mathrm{J}$. clin. Invest. 1957, 36, 1508.

10. Seegmiller, J. E., Laster, L., and Liddle, L. V. Failure to detect consistent overincorporation of glycine-1- $\mathrm{C}^{14}$ into uric acid in primary gout. Metabolism 1958, 7, 376.

11. Wyngaarden, J. B. Normal glycine-C ${ }^{14}$-incorporation into uric acid in primary gout. Metabolism 1958, 7, 374.

12. Gutman, A. B., Yü, T. F., Black, H., Yalow, R. S., and Berson, S. A. Incorporation of glycine-1-C $C^{14}$, glycine-2- $\mathrm{C}^{14}$ and glycine- $\mathrm{N}^{15}$ into uric acid in normal and gouty subjects. Amer. J. Med. 1958, 25, 917.

13. Seegmiller, J. E., Grayzel, A. I., Laster, L., and Liddle, $\mathrm{L}$. Uric acid production in gout. J. clin. Invest. 1961, 40, 1304. 
14. Laster, L., and Muller, A. F. Uric acid production in a case of myeloid metaplasia associated with gouty arthritis, studied with $\mathrm{N}^{15}$-labeled glycine. Amer. J. Med. 1953, 15, 857.

15. Yü, T. F., Weissmann, B., Sharney, L., Kupfer, S., and Gutman, A. B. On the biosynthesis of uric acid from glycine- $\mathrm{N}^{15}$ in primary and secondary polycythemia. Amer. J. Med. 1956, 21, 901.

16. Van Scott, E. J., and Reinertson, R. P. Morphologic and physiologic effects of chemotherapeutic agents in psoriasis. J. invest. Derm. 1959, 33, 357.

17. Praetorius, E., and Poulsen, H. Enzymatic determination of uric acid; with detailed directions. Scand. J. clin. Lab. Invest. 1953, 5, 273.

18. Liddle, L., Seegmiller, J. E., and Laster, L. The enzymatic spectrophotometric method for determination of uric acid. J. Lab. clin. Med. 1959, 54, 903.

19. Archibald, R. M. Colorimetric measurement of uric acid. Clin. Chem. 1957, 3, 102.

20. Grayzel, A. I., Liddle, L., and Seegmiller, J. E. Salicylate induced hyperuricemia and the diagnosis of gout. In preparation.

21. Geren, W., Bendich, A., Bodansky, O., and Brown, G. B. The fate of uric acid in man. J. biol. Chem. 1950, 183, 21.

22. Hawk, P. B., Oser, B. L., and Summerson, W. H. Practical Physiological Chemistry, 13th ed. New York, McGraw-Hill, 1954, p. 911.

23. Folin, O. Laboratory Manual of Biological Chemistry, 3rd ed. New York, D. Appleton, 1922, p. 299.

24. Rittenberg, D. The preparation of gas samples for mass spectrographic isotope analysis in Preparation and Measurement of Isotopic Tracers, D. W. Wilson, A. O. C. Nier and S. P. Reimann, Eds. Ann Arbor, J. W. Edwards, 1946, p. 31.
25. Evans, E. I., Purnell, O. J., Robinett, P. W., Batchelor, A., and Martin, M. Fluid and electrolyte requirements in severe burns. Ann. Surg. 1952, 135, 804.

26. Kuzell, W. C., Schaffarzick, R. W., Naugler, W. E., Koets, P., Mankel, E. A., Brown, B., and Champlin, B. Some observations on 520 gouty patients. J. chron. Dis. 1955, 2, 645.

27. Sorenson, L. B. Degradation of uric acid in man. Metabolism 1959, 8, 687.

28. Benedict, J. D., Forsham, P. H., Roche, M., Soloway, S., and Stetten, DeW., Jr. The effect of salicylátes and adrenocorticotropic hormone upon the miscible pool of uric acid in gout. J. clin. Invest. 1950, 29, 1104.

29. Bishop, C., Garner, W., and Talbott, J. H. Pool size, turnover rate, and rapidity of equilibration of injected isotopic uric acid in normal and pathological subjects. J. clin. Invest. 1951, 30, 879.

30. Wyngaarden, J. B., Blair, A. E., and Hilley, L. On the mechanism of overproduction of uric acid in patients with primary gout. J. clin. Invest. 1958, 37, 579.

31. Craddock, C. G., Jr., Perry, S., and Lawrence, J. S. The dynamics of leukopenia and leukocytosis. Ann. intern. Med. 1960, 52, 281.

32. Rothberg, S. Personal communication.

33. Bien, E. J., and Zucker, M. Uricolysis in normal and gouty individuals. Ann. rheum. Dis. 1955, 14, 409.

34. Bishop, C., Rand, R., and Talbott, J. H. The effect of Benemid (p-[di-n-propylsulfamyl]-benzoic acid) on uric acid metabolism in one normal and one gouty subject. J. clin. Invest. 1951, 30, 889.

35. Seegmiller, J. E. Unpublished data. 